\title{
THE DIFFERENCE OF STUDENTS' MATHEMATICAL REPRESENTATION ABILITY BY USING INSTRUCTION OF PROBLEM BASED LEARNING AND DIRECT INSTRUCTIOIN IN GRADE $X$
}

\author{
Elfan Syahputra, Mukhtar \\ FMIPA Unimed Medan
}

Email: elfanmook@yahoo.com

\begin{abstract}
This research is quasi-experiment. The purpose of this research is to know whether students' mathematical representation by using instruction of problem based learning classroom is higher than direct instruction classroom at SMA Swasta Panca Budi Medan.The population of this research is students of SMA Swasta Panca Budi Medan which consists of 14 classes, whereas the sample consists of 2 classes, namely, X-MS1 as experimental class consists of 32 students and X-MSA as control class consists of 30 students. Experimental class used Problem Based Learning and control class used Direct Instruction. Collecting data technique of this research is mathematical representation test given in the end of learning either in experimental class or control class. The type of this test is essay test. Before doing hypothesis test, the normality and the homogeneity test should be done. The result of those tests, sample was taken from normal distributed and homogeneous population. The data analysis of experimental class by using t-test with significance level $\alpha=0.05$, it was obtained that $t_{\text {calculation }}>t_{\text {table }}$ then $H_{0}$ is rejected and $H_{a}$ is accepted .It can be concluded that students' mathematical representation ability by using instruction of problem based learning is higher than direct instruction in grade X. The research that has been done, researcher suggested that Problem based learning can be as consideration to teachers in enhancing senior high school students' mathematical representation ability. Teacher intends to use problem based learning, needed preparation and used time effectively in its implementation. The result and instrument of this research can be used as consideration to implement problem based learning in a different class grades and subjects for the future researchers.
\end{abstract}

Keyword: Quasi-experiment, Representation, Problem Based Learning, Direct Instruction

Background

The most important thing to increase the progress of a nation is human resources. Indonesia is categorized as a developing country and the quality of National Education has very wide impacts in all aspects of human's life. By education, human will be able to solve various problems and difficulties of life. Therefore, the purposes of education are as a selfbuilder, shaper, and developer. Globalization requires people to have adequate education in order to compete Learning methematics will be meaningful to students if it is done in accordance with the students' initial knowledges. From the beginning of knowledge, teachers provide materials /learning resources that correspond to the basic competencies required. Then conditioned with the guidance of the teachers to make students active in constructing their own knowledge. Learning will be meaningful if teachers relate the new knowledge with some experiences which has contained one of

Elfan Syahputra, Mukhtar. 2015. The Difference of Students' Mathematical Representation Ability by Using Instruction of Problem Based Learning and Direct Instruction in Grade $X$. Inspiratif. Vol. 1 No. 1, hal. 32-41 
the important factors in learning mathematics.

The main problem in formal education (school) is the low absorptive capacity of the learners. This is proven by the result of the students' learning which is very low. Achievement is certainly the result of learning conditions that are conventional and will not make the students aware of participants, how to actually learn it. In other words, the learning process is still dominated by the teachers and not provide access for the students to develop independently through discovery in the process of thinking (Trianto, 2010).

Mathematics is one of those subjects that has a very close concepts related with daily life. This means that the learning is not enough if just to teach mathematics conceptually, but students also need to understand how to use the concept significantly.

In learning mathematics, students must have comprehension, skills, and knowledge which these aspects are known and can be done by teachers and students. NCTM (in Effendi: 2012) states that the expected goals in learning mathematics are to set of five standard process that must be owned by students namely problem solving ability, communication ability, connection ability, reasoning ability, and representation ability. As stated by Fadillah (2011) that beside solving problem ability, reasoning, communication, and connection, entering representation as component of standard process in Principles and Standards for School Mathematics is very exact since for mathematical thinking and communicating of mathematical ideas, the students need to represent on various form of mathematical representation. Moreover, it can't be denied that mathematics objects are abstract so that to learn and understand abstract ideas requires representation.

Representation is a sign or a configuration of signs, characters, or objects which mark and configuration is able to stand to represent, describe, or represent something other than itself (Cuoco and Curcio, 2001: 3).

Kalathin and Sherin (2000) more simply stated that the representation was made by students as externalizations their work so that it can be used as information. Next in mathematical psychology, representation is a description of the relationship between objects and symbols (Hwang, et al: 2007)

Meanwhile, Jones (in Fadillah: 2011) also explain three reason why representation as a standard process, namely (1) Basic ability must be owned by students to build a concept and mathematical thinking is doing translation on various representations type smoothly; (2) Teacher should provide mathematical ideas through various representations since the situation can provide enormous influence to students in learning mathematics; and (3) Teachers should provide various exercises to students since the students really need these exercises to build their representations so that having ability and good in understanding the concept and flexible can be used on problem solving.

This is consistent with the opinions expressed by Yuniawatika (2011) which said that students can be encouraged to find and create various representations that could be used as a thinking way in expressing their knowledge from abstract to concrete and the situation can be concluded that mathematical representations ability as a way to increase and express mathematical thinking ability of students.

Elfan Syahputra, Mukhtar. 2015. The Difference of Students' Mathematical Representation Ability by Using Instruction of Problem Based Learning and Direct Instruction in Grade $X$. Inspiratif. Vol. 1 No. 1, hal. 32-41 
Rahmi (in Hutagaol: 2013) said that diagram, picture, table, chart, mathematical statement, written text, also combination of all as representations variety can be used by students in expressing mathematical ideas. Variety of representations such as table, picture, graph, and another symbol are part of mathematics that can't be separated since mathematical representations is a part of mathematics.

But based on last situation, students mathematical representations ability in school is still less considered since many students who don't understand the mathematical representations ability.

Disinterest of student in mathematics subject caused by the student's ignorance of the usefulness of materials studied in mathematics into their daily lives. In addition, teachers only focus on books when teaching.

A wide range of innovative learning strategies that are considered the development of students's cognitive abilities and independence. One model is Problem Based Learning (PBL). PBL is a learning model that engages students to solve a problem through the stages of the scientific method so that students may learn the knowledge related to the problem and having skills to solve the problem. Objectivities to be achieved in Problem Based Learning is a student's ability to think critically, analysis, systematic and logical to look for an alternative solution through the exploration of the empirical data in order to develop a scientific attitude (Sanjaya, 2008). So, the learning goals expected to be achieved is to improve student's learning outcomes and to develop a scientific attitude of the student.

Problem Based Learning model begins with problem, then students deepen their knowledge about what they have already known and what they need to know to solve the problem. (Duch in
Riyanto, 2010) states that: Problem Based Learning is learning model that exposes learners to the challenge of "learning to learn". Students actively work in groups to seek the solutions of problems. The problem is as a reference for students to formulate, analyze, and solve. Problem Based Learning model is intended to develop students's critical thingking, analytical, and to find and to use appropriate resources for learning.

In this study, the role of teachers is asking problems, providing encouragement, motivation, and teaching matherials, as well as providing the necessary facilities for learners in the process of reasoning. In addition, teachers also provide support the finding and intellectual development of students.

In the learning of problem based learning students are required to undertake the process of solving problems presented by digging out as much. This experience is indispensable in everyday of life where the growth of mindset and work patterns of a person depends on how he positioned himself in the study. Problem Based Learning is learning using a real problem (the fact) that is presented at the beginning of learning. First step is understanding of the problem so that the necessary reasoning abilities, and then probed for known solutions to these problems.

Direct Instruction as the other teaching models, direct instruction can be described in terms of three features: (1) the type of learner outcomes it produces, (2) its syntax or overall flow of instructional activities, and (3) its learning environment.

Briefly, direct instruction was design to promote mastery of skills (procedural knowledge) and factual knowledge that can be taught in a step by step fashion. The model is not intended to accomplished social learning outcomes or higher-level thinking, nor is it effective for these uses. Direct instruction is a teacher centered model

Elfan Syahputra, Mukhtar. 2015. The Difference of Students' Mathematical Representation Ability by Using Instruction of Problem Based Learning and Direct Instruction in Grade $X$. Inspiratif. Vol. 1 No. 1, hal. 32-41 
that has five steps: establishing set, explanation and/ or demonstration, guided practice, feedback, and extended practice

Based on problems above, the writer is interested to know is students's mathematical representation ability using problem based learning higher than direct instruction in grade X SMA Panca Budi Medan Academic Year 2014/2015.

\section{RESEARCH METHODOLOGY}

This research type is quasiexperiment, which aims to find out whether students's mathematical representation ability using problem based learning higher than direct instruction. The research was conducted at SMA Panca Budi Medan grade X academic year 2014/2015. The research was held on August-September year 2014 during five sessions each experiment class and control class. The distribution are: 1 meetings for posttest and 3 meetings for learning treatment

The population in this research are all of students at grade X SMA Panca Budi Medan academic year 2014/2015, that contain of 4 classes. Obtained that two samples will be subjected to treatment namely class $\mathrm{X}-\mathrm{a}$ as experiment class was taught using probelm based learning and class $\mathrm{X}-\mathrm{b}$ as control class was taught using Direct Instruction.

The objects in this research is an effort to increase students' ability to think creatively by applying problem based learning model on Angel InterConnection subject of MTs Swasta Mawaridussalam Deli Serdang academic year 2014/2015.

\section{Design of Research}

This research design is posttest only control group design. The treatment (X) that is given to experimental class that is by using Problem Based Learning. After doing the treatment, both of class will be given the mathematical representation (0).

This research design can be presented

Experiment : $\mathrm{X} \quad \mathrm{O}_{1}$

Control : $\quad \mathrm{O}_{2}$

\section{Procedure of Research}

Procedure of research is the steps of activity will be conducted in this research. The procedure in this reseaarch are:

1. Preparation phase :

a. Scheduling research

b. Instructional plan using model of probelm based learning and dirrect instruction on the subject statistics. Created lesson plan each class in 4 sessions

c. Setting up data collection tool, in the form of posttest

d. Validate a matter of research instruments

2. Implentation Phase :

a. The samples were randomly taken two clasess: one class used as the experimental class and the control class to be the class

b. Gives a test protest given before applying of study in the two samples. Initial results analyzed to see if the beginning of control class capability equal or not

c. Instructional held into two classes with same materials and time, just learning different. To be given treatment that is experimental class of probelm based learning while the control class treatment given direct instruction.

3. Last Phase

a. To process postest data for each class

b. To see the different between experiment class and control class in order to determine whether mathematical representation ability of students better than Direct Instructional model using test of tone way

c. To conclude the result of research

Elfan Syahputra, Mukhtar. 2015. The Difference of Students' Mathematical Representation Ability by Using Instruction of Problem Based Learning and Direct Instruction in Grade $X$. Inspiratif. Vol. 1 No. 1, hal. 32-41 


\section{Instrument of Research}

The research instrument is a tool for measuring variables in a variety of research designs that can be divided into test and scale. Therefore the instrument in this research is a test. The test are observation test and test of student's mathematical representation ability, namely: Initial test, Test Student Mathematical Representation ability.

\section{Data Analysis Technique}

After data is obtained, then data is processed using data analysis technique with softwere spss 18.0 for windows . In this research, data will be processed posttest data in experiment and control clas the steps of data analyze are : means score, standard deviation, normality test, homogenity test and compare means (t-test).

\section{RESULT AND DISCUSSION}

\section{Research Result Description}

The research is executed in order to determine the differences of mathematical representation ability using the problem based learning and direct instruction. There are two classes used in the research, namely: experiment class and control class. Experiment class applies problem based learning, meanwhile class control applies direct instruction. The data analysis is obtained from mathematical representation ability test or post-test. Post-test is executed in the experiment class with the total number of students of 32 from class XMS 1, and the control class with the total number of students of 30 from class XMS A.

\section{The Description of Students' Mathematical Representation Ability}

In order to find the difference of mathematical representation ability, we can see from the post-test descriptive data table. The post-test data of experiment class and control class is processed in Microsoft Excel.

\section{Table 1 The Result Post-test of Mathematical Representation Ability}

\begin{tabular}{|c|c|c|c|c|c|}
\hline \multirow[b]{2}{*}{ Class } & \multirow[b]{2}{*}{$\begin{array}{l}\text { Ideal } \\
\text { Score }\end{array}$} & \multicolumn{4}{|c|}{ Posttest of Mathematical Representation Ability } \\
\hline & & $\begin{array}{l}\text { Minimum } \\
\text { Score }\end{array}$ & $\begin{array}{l}\text { Maximum } \\
\text { Score }\end{array}$ & Mean & \begin{tabular}{|l|} 
Standard \\
Deviation \\
\end{tabular} \\
\hline Experiment & 32 & 16 & 32 & 25,2 & 4,4 \\
\hline Control & 32 & 10 & 30 & 20,1 & 5,2 \\
\hline \multicolumn{4}{|c|}{$\begin{array}{l}\text { Based on the data above, we now have } \\
\text { that the average of experiment class is } \\
\text { better than control class, but the standard } \\
\text { deviation of experiment class is lower } \\
\text { than control class. It means that the } \\
\text { score distribution of control class is } \\
\text { more varied than experiment class. The } \\
\text { data above also can be represented into } \\
\text { histogram. Histogram shows the } \\
\text { minimum score, maximum score, mean } \\
\text { and standard deviation of post-test data }\end{array}$} & \multicolumn{2}{|c|}{ 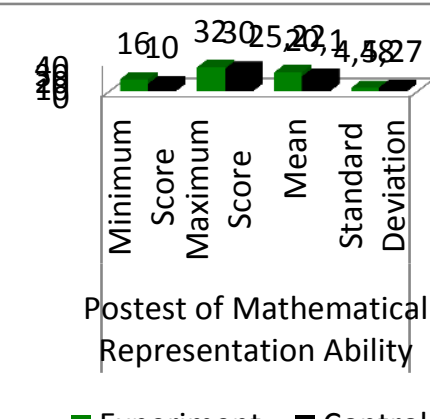 } \\
\hline
\end{tabular}

of both classes.

\section{Figure 1 Histogram Post-test of Students' Mathematical Representation Ability}

Elfan Syahputra, Mukhtar. 2015. The Difference of Students' Mathematical Representation Ability by Using Instruction of Problem Based Learning and Direct Instruction in Grade $X$. Inspiratif. Vol. 1 No. 1, hal. 32-41 
Based on the description above, we can see that there is the difference of students' mathematical representation ability by using instuction of problem based leaning and direct instruction class. But, to see whether the difference is significant or not, we need to do the comparison mean test. Before doing comparison mean test, it will be tested the normality and homogeneity of the post-test data of experiment class and control class beforehand.

\section{The Description of Matemathical Represention Test}

Matemathical Representation Test is made based on 3 indicators of its; 1) be able to classify the data from picture and be able to sketch diagram, 2) be able to solve mathematical problem using mathematical expression, and 3) be able to write the steps of mathematical problem and interpret. In this test, indicator 1 is in problem number $2 \mathrm{a}$ and $4 \mathrm{a}$, indicator 2 is in problem number $2 \mathrm{~b} 3 \mathrm{a}$ and $3 \mathrm{~b}$, and indicator number 3 is in problem number 1 and $3 \mathrm{c}$. Problem number 1 and $3 \mathrm{c}$ are in basic competence of presenting the real data in tables or diagram/ plots in accordance with the specific information to be communicated, problem number $2 \mathrm{a}$ and $4 \mathrm{a}$ are in basic competence of describing the data in tables or diagrams/ plots in accordance with the specific information to be communicated, and problem number $2 \mathrm{~b} 3 \mathrm{a}$ and $3 \mathrm{~b}$ are in basic competence describing the various presentations of data in tables or diagrams / plots suitable for communicating information from a data set through a comparative analysis of a wide variety of data presentation

Table 3.2 Mean percentages of experimental and control class each indicator

\section{Analysis of Research Data 1 Normality Test}

Normality test is executed in order to cognize whether the data sample came from normal distribution or not. The data that is later known have been distributed or not is the post-test data from experiment class and control class. For the normality test, the Kolmogorov-smirnov is used with the significant values of $(\alpha)$ is $5 \%(0.05)$ by using SPSS version 18.0 for windows.

\begin{tabular}{|c|c|c|c|}
\hline \multirow{2}{*}{$\begin{array}{l}\text { Indic } \\
\text { ator }\end{array}$} & \multirow{2}{*}{$\begin{array}{c}\text { No. } \\
\text { of } \\
\text { probl } \\
\text { em }\end{array}$} & $\begin{array}{c}\text { Experim } \\
\text { ental } \\
\text { Class }\end{array}$ & $\begin{array}{l}\text { Contro } \\
\text { I Class }\end{array}$ \\
\hline & & $\begin{array}{c}\text { Percenta } \\
\text { ge of } \\
\text { Mean } \\
\end{array}$ & $\begin{array}{c}\text { Percen } \\
\text { tage of } \\
\text { Mean } \\
\end{array}$ \\
\hline \multirow{2}{*}{$\begin{array}{c}\text { Visua } \\
\text { l }\end{array}$} & $2 \mathbf{a}$ & $73.43 \%$ & $72.5 \%$ \\
\hline & $4 a$ & $66.25 \%$ & $\begin{array}{c}64.16 \\
\%\end{array}$ \\
\hline \multirow[t]{3}{*}{$\begin{array}{c}\text { Equat } \\
\text { ion }\end{array}$} & $2 b$ & $77.34 \%$ & $\begin{array}{c}65.83 \\
\% \\
\end{array}$ \\
\hline & $\mathbf{3 a}$ & $96.09 \%$ & $92.5 \%$ \\
\hline & $3 b$ & $86.71 \%$ & $\begin{array}{c}34.16 \\
\%\end{array}$ \\
\hline \multirow[t]{2}{*}{$\begin{array}{c}\text { Writt } \\
\text { en }\end{array}$} & 1 & $99.21 \%$ & $\begin{array}{c}96.67 \\
\%\end{array}$ \\
\hline & $3 c$ & $57.81 \%$ & $17.5 \%$ \\
\hline
\end{tabular}

Elfan Syahputra, Mukhtar. 2015. The Difference of Students' Mathematical Representation Ability by Using Instruction of Problem Based Learning and Direct Instruction in Grade $X$. Inspiratif. Vol. 1 No. 1, hal. 32-41 
Table 2 One-sample Kolmogorov-Smirnov test

One-Sample Kolmogorov-Smirnov Test

\begin{tabular}{|ll|r|r|}
\hline & & Experiment & \multicolumn{1}{|c|}{ Control } \\
\hline $\mathrm{N}$ & & 32 & 30 \\
Normal Parameters & & 25.22 & 20.10 \\
& Mean & 4.485 & 5.268 \\
Most Extreme Differences & Std. Deviation & .139 & .122 \\
& Absolute & .073 & .122 \\
& Positive &. .139 & -.066 \\
Kolmogorov-Smirnov Z & Negative & .784 & .666 \\
Asymp. Sig. (2-tailed) & & .570 & .767 \\
\hline
\end{tabular}

a. Test distribution is Normal.

b. Calculated from data.

Based on the KolmogorovSmirnov test table above, it can be seen that the significant value of experiment class is 0.570 and the significant values of control class is 0.767 . Based on the decision-making of the normality test above, it can be concluded that the significant values of experiment class and control class is higher than 0.05, sample data is from the population of normal-distributed.

\section{Homogenity Test}

Following the knowing of that the data sample is from the normal-distributed population, then the data must be examined with the next test, namely homogeneity test. The homogeneity test is undertaken in order to know whether the data have homogeneity variants or not using the Levene Test with $\alpha$ of $5 \%$.

Table 3. Homogeneity variance test

\begin{tabular}{|c|c|c|c|c|c|}
\hline \multicolumn{3}{|c|}{ Levene Statistic } & df1 & df 2 & Sig. \\
\hline \multirow[t]{4}{*}{ Score } & Based on Mean & 1,784 & 1 & 55 & , 187 \\
\hline & Based on Median & 1,524 & 1 & 55 & ,222 \\
\hline & Based on Median and with adjusted df & 1,524 & 1 & 54,559 & ,222 \\
\hline & Based on trimmed mean & 1,791 & 1 & 55 & , 186 \\
\hline
\end{tabular}

Based on The Lavene test table above, it can be seen that the probability value (Sig.) of score Based on Mean is 0,187. Based on the criteria of the decisionmaking above, can be conluded that the significant values is higher than 0.05 . So there is no variant difference between post-test data of experimental class and control class.

\section{Compare Means Test (One-tailed)}

Based on the normality and homogeneity test of post-test data, it can be concluded that sample is normaldistributed and homogeneous. Then the next step is to determine whether there is the difference or not of compare means significantly by using Independent Sample t-test with $\alpha$ of $5 \%$.

Elfan Syahputra, Mukhtar. 2015. The Difference of Students' Mathematical Representation Ability by Using Instruction of Problem Based Learning and Direct Instruction in Grade $X$. Inspiratif. Vol. 1 No. 1, hal. 32-41 
Based on the table above, it can be seen that the value of $t_{\text {calculation }}$ is 4.128 with significant value of $5 \%(0.05)$. Based on the post-test data that is acquired from experiment and control class which consist of 62 students $(\mathrm{N}=62)$, then the degree of freedom $(\mathrm{df})$ is $62-2=60$. Then the value of $t_{\text {table }}$ is 1.671. It shows that $t_{\text {calculation }}>t_{\text {table }}$, it means that $\mathrm{H}_{0}$ is rejected and $\mathrm{H}_{a}$ is accepted. Then it can be concluded that students' mathematical represantation ability using problem based learning are higher than direct instruction.

\section{Analysis of Observation Sheet}

Observation was done to see the activty of teacher, students, and teacher and students altogether during learning process problem based learning occured. It was done by researcher's partner who is on a level with researcher.

From the observation, it is known that in the first meeting when teacher was checking prerequisite ability of students by debriefing, just a few students responded the question from teacher. And also in the first and second meeting, there were still groups that did not give their contribution in front of the class. For instance, there were three groups in the first meeting and two groups in the second meeting. They had reason that their answer is the same with other groups. Moreover, when discussion class was occuring, just a few students intended to convey their opinion. Yet when they were solving routine problems in SAS, all students felt impassioned. Students' response when teacher proposed several questions to them was well enough. On the next day, students' contribution in class discussion had progression. Teacher argues that this progressing happened since students were able to adapt with the new learning style and also adapt to the teacher.

\section{Research Discussion}

Based on the research results that have been presented above, it shows that the learning using problem based learning model is significantly better in order to improve the students' mathematical representation ability than direct instruction. If we notice learning characteristics of both approaches is a fair thing that difference happens. The advantages of the problem based learning model can be seen from its characteristics and whether its implementation maximized or not, it will be possible the better learning process conducted. These advantages can be seen from teaching materials that is used, teacher's roles, and the roles of the student in the learning process.

First, teaching material that is used by teacher is as Student Activity Sheets that contains some problems that are presented at the beginning of learning. Those problems direct students to solve reading presentation of the data in the form of line diagram, pie diagram and bar diagram, determining the kinds of diagram, identifying the value of data displayed in table and diagram, presenting data in diagram of bar, line and pie and interpreting the data in a diagram of bar, lines, and circles. Those are made students more critical to learn. In addition, the data that are presented in those problems are the data obtained from their own, example: weight, height, number of shoes, so that they did not just imagine the problem but could observe the problems that they faced directly. This could help students of finding mathematical concepts. As with the control class which used the direct instruction which prioritizes the results rather than the process. Students only receive a ready-made mathematical concept from teacher without finding the concept themselves. Then proceed with giving exercises and home works. It is certainly difficult to make students understand mathematical concepts.

Elfan Syahputra, Mukhtar. 2015. The Difference of Students' Mathematical Representation Ability by Using Instruction of Problem Based Learning and Direct Instruction in Grade $X$. Inspiratif. Vol. 1 No. 1, hal. 32-41 
Second, the role of the teacher is as a facilitator, it means that teacher gives directives in order that the material being studied can be understood and interpreted by students through problems given in the learning process. Students worked independently or together in their own group. They learned and discussed actively so that they showed progressing in learning in every meeting. Besides being a facilitator, the teacher also acted as an organizer. As an organizer, a teacher did not only make students in group and let them work together with their peers, but teacher motivated students so that each student can fully participated in group activities. In the control class, the teacher gave the material to the students then wait for students to ask questions in case they don't understand yet. So it is clear that the differences of teacher roles in learning process in the experimental class and the control class.

Third, the activities of students during the learning process. Students' activities in problem based learning class are to understand the problem, to solve problems, and to share the answers each group. In each meeting, the students were divided into 5 groups of 6 students. In each meeting, the students' activity in the experimental class increased positively, it means that their spirit and curiosity in learning mathematics is progressing and increasing. Students expressed their ideas in their own group, discussed strategies, and mathematical concept that used to direct them to build their own understanding. This situation is also happened in research that was conducted by Armanto (2002).

Based on the analysis results of posttest data, it is known that average of posttest score of experimental and control class respectively is 25.22 and 20.10. it shows that posttest score of experimental class is better than control class. In other words, students' mathematical representation experimental class is higher than control class.

The arrangement of mathematical representation problems based 3 indicators, 1) they are be able to classify the data from picture and be able to sktech diagram ,2) be able to mathematical probelm using mathematical expression and 3) be able to write mathematical probelm and interpret. For indicator 1 in problem number $2 \mathrm{a}$ and $4 \mathrm{a}$, mean percentage of experimental class is higher than control class. It might happen since students in experimental class used data presentation, so that they could understand more about classifying the objects based on its concepts than students in control class. For indicator 2 in problem number $2 \mathrm{~b} 3 \mathrm{a} 3 \mathrm{~b}$, mean percentage of experimental class is also higher than control class. It might happen since students in experimental class were taught by problem in the beginning of learning, so that they could understand more how to solve the probelms. For indicator 3 in problem number 1 and $3 \mathrm{c}$, mean percentage of experimental class is higher than control class. It might happen since most of the students in experimental class have understood the concepts of a collecting data problem, observe , sharing ideas, and communication they did during learning process, so that they could use them to solve the routine problem they faced.

Judging from the post-test scores which obtained by students, minimum and maximum scores are 16 and 32 respectively, where the students who have the lowest score is 1 students and the highest is 1 student. Ideal score for a given problem posttest is 32 . If we observe students' answers, it will be obvious how far students understand the problem. It can be seen from the indicators of understanding concepts that are satisfied in each problem. From the answers, the students who obtained

Elfan Syahputra, Mukhtar. 2015. The Difference of Students' Mathematical Representation Ability by Using Instruction of Problem Based Learning and Direct Instruction in Grade $X$. Inspiratif. Vol. 1 No. 1, hal. 32-41 
the lowest scores, they were weak in applying concepts into routine problems.

\section{Conclusion}

Based on the result of research and discussion can be conclude that students' mathematical representation ability by using instruction of probelm based learning higher than direct instruction in grade X SMA Panca Budi Medan. Learning process of mathematics by using instruction of problem based learning needs longer time since in its learning, students receive information from teacher indirectly, so that it is needed preparation and used time effectively in its implementation.

\section{References}

Baden, M.S., and Major, C.H., 2004. Foundation of Problem Based Learning, Mmpg Books Ltd, Britain

Cuoco, A. A., and Curcio, F, R., 2001. The Roles of Representation in School Mathematics, NTCM

$$
\begin{array}{crr}
\text { Effendi, 2012. } & \multicolumn{2}{r}{\text { Pembelajaran }} \\
\text { Matematika } & \text { Dengan } & \text { Metode } \\
\text { Penemuan } & \text { Terbimbing Untuk } \\
\text { Meningkatkan } & \text { Kemampuan } \\
\text { Representasi dan } & \text { Pemecahan } \\
\text { Masalah Matematis } & \text { Siswa SMP, } \\
\text { Jurnal Pendidikan } & \text { Penelitian, } \\
\mathbf{1 3}(\mathbf{2}), 2 & &
\end{array}
$$

Fadillah, S., 2011. Penerapan Pembelajran Matematika Dengan Strategi React Untuk Meningkatkan Kemampuan Koneksi dan Representasi Matematik Siswa Sekolah, Jurnal Pendidikan Matematika, 8: 104-110

Hutagol, K. 2013. Pembelajaran Kontekstual Untuk Meningkatkan Kemampuan Representasi Matematis Siswa Sekolah Menengah, Jurnal Ilmiah Program
Studi STKIP Siliwangi Bandung Matematika, 2(1), 85-9

Hwang, et al., 2007. Multiple Representation Skills and Creativity Effects on Mathematical Problem Solving using a Multimedia Whiteboard System, Educational Technology \& Society, 10(2), 191212

Trianto.2010. Mendesain Model Pembelajaran Inovatif Progresif, Kencana Prenada Media Grup, Jakarta

Yuniawatika.2011. Meningkatkan Kemampuan Representasi Multipel Matematika Siswa SMP Melalui Pembelajaran Dengan Pendekatan Open Ended, Jurnal Pendidikan Matematika,15: 105-119

Elfan Syahputra, Mukhtar. 2015. The Difference of Students' Mathematical Representation Ability by Using Instruction of Problem Based Learning and Direct Instruction in Grade $X$. Inspiratif. Vol. 1 No. 1, hal. 32-41 